\title{
High Entropy Alloys Behaviour During Welding
}

\author{
ELENA SCUTELNICU ${ }^{1}$, GEORGE SIMION ${ }^{1}$, CARMEN CATALINA RUSU ${ }^{1 *}$, \\ MARIUS CORNELIU GHEONEA ${ }^{1}$, IONELIA VOICULESCU ${ }^{2}$, VICTOR GEANTA ${ }^{2}$ \\ ${ }^{1}$ Dunarea de Jos University of Galati, 47 Domneasca Str., 800008, Galati, Romania \\ ${ }^{2}$ University Politehnica of Bucharest, 313 Splaiul Independentei, 060042, Bucharest, Romania
}

\begin{abstract}
The High Entropy Alloys have been developed in the last two decades by mixing at least four chemical elements in equiatomic or quasi-equiatomic proportions. Due to the large range of structures and outstanding properties, these advanced materials can be used for structural, high-temperature, wear-resistant, corrosion-resistant, oxidation-resistant, and electrical elements. In order to extend the applicability area of High Entropy Alloys and to improve the knowledge in terms of their behaviour, the researchers worldwide have investigated the phenomena generated by the welding process and its effects produced on their properties. The findings have revealed that these special alloys can be recommended to be used both in high and low-temperature applications. This paper presents a review focused on the weldability and behaviour of CoCrFeMnNi, AlCoCrCuFeNi, AlCrFeCoNi, and CoCrFeNi alloys during Friction Stir Welding, Electron Beam Welding, Laser Beam Welding, and Tungsten Inert Gas. Original results related to the weldability and behaviour of new AlCrFeMnNi alloys developed and subjected to Shielded Metal Arc Welding, as a technical solution for performing morpho-functional structures used in the military field, are presented and discussed, too. The experimental results demonstrated that an appropriate selection of joining technique and filler metal, as well as an optimal combination of process parameters led to performing quality joints, free of defects.
\end{abstract}

Keywords: High Entropy Alloys, CoCrFeMnNi, AlCoCrCuFeNi, AlCrFeCoNi, CoCrFeNi, AlCrFeMnNi, weldability.

\section{Introduction}

In the beginning, the conventional alloys were traditionally developed by using a model based on the existence of a "basic chemical element" [1]. Through this elaboration method, a chemical element or sometimes two main chemical elements, i.e. Fe in steel or Ni in superalloys, were chosen and, in addition, low percentages of alloying elements were added, in order to obtain alloys with superior properties. Almost two decades ago, a new method of alloying, meaning a combination of several chemical elements in an equimolar or almost equimolar composition, has been proposed and advanced High Entropy Alloys (HEAs) with preserved properties at high-temperature variations have been achieved [1]. By definition, the HEAs contain at least four main chemical elements, with 5...35\% atomic concentrations. To improve the mechanical properties, these alloys can be supplementary alloyed with other chemical elements, in a concentration of less than 5\% [2-10]. Consequently, it is possible to obtain alloys with outstanding mechanical properties [11-20], such as the $\mathrm{Al}_{20} \mathrm{Li}_{20} \mathrm{Mg}_{10} \mathrm{Sc}_{20} \mathrm{Ti}_{30}$ alloy which is characterised by $2.67 \mathrm{~g} / \mathrm{cm}^{3}$ mass density and $5.9 \mathrm{GPa}$ hardness, similar to high hardness steels [21]. Another example is the $\mathrm{Fe}_{25} \mathrm{Co}_{25} \mathrm{Ni}_{25} \mathrm{Al}_{10} \mathrm{Ti}_{15}$ alloy that has a tensile strength of $1.82 \mathrm{GPa}$, reaching up to the ultimate tensile strength of $2.52 \mathrm{GPa}$ [22].

\footnotetext{
*email: carmen.rusu@ugal.ro
} 


\section{Materials and methods}

Based on the literature studied for developing this review, more HEAs, whose chemical composition is presented in Table 1, have been identified [23 - 33]. For the conventional alloys, the mechanical properties are determined by the dominant chemical element. For example, Young's module has a value of about $200 \mathrm{GPa}$ for alloys whose main element is Fe, $110 \mathrm{GPa}$ for Ti-based alloys, and around of $75 \mathrm{GPa}$ for the Al-based ones. As regards the HEAs properties, Young's module, for instance, is determined by the added chemical elements but may have a different value. Thus, the $\mathrm{CoCrFeNiCuAl}_{0.5}$ alloy has the Young modulus of $24 \mathrm{GPa}$, which is much lower than the modulus of any constituent chemical element (Figure 1) [34]. Another important feature of these advanced alloys is the hardness characteristic.

Table 1. Chemical composition of several High Entropy Alloys [23 - 33]

\begin{tabular}{|c|c|c|c|c|c|c|}
\hline Alloy & \multicolumn{6}{|c|}{ Chemical composition [\%] } \\
\hline $\mathrm{Al}_{0.5} \mathrm{CoCrFeNi}$ & $\mathrm{Al}-11.11$ & $\mathrm{Co}-22.22$ & $\mathrm{Cr}-22.22$ & $\mathrm{Fe}-22.22$ & $\mathrm{Ni}-22.22$ & \\
\hline $\mathrm{CoCrFeMnNi}$ & Co -19.8 & $\mathrm{Cr}-19.94$ & $\mathrm{Fe}-20.6$ & $\mathrm{Mn}-19.34$ & $\mathrm{Ni}-20.32$ & \\
\hline $\mathrm{CoCrFeNiAl}_{0.3}$ & $\mathrm{Co}-23.26$ & $\mathrm{Cr}-23.26$ & $\mathrm{Fe}-23.26$ & $\mathrm{Ni}-23.26$ & $\mathrm{Al}-6.9$ & \\
\hline $\mathrm{Al}_{0.3} \mathrm{CrFe}_{1.5} \mathrm{MnNi}_{0.5}$ & $\mathrm{Al}-3.5$ & $\mathrm{Cr}-22.19$ & $\mathrm{Fe}-36.82$ & $\mathrm{Mn}-23.67$ & $\mathrm{Ni}-13.76$ & \\
\hline $\mathrm{AlMo}_{0.5} \mathrm{NbTa}_{0.5} \mathrm{TiZr}$ & $\mathrm{Al}-21.34$ & Mo -13.56 & $\mathrm{Nb}-24.6$ & $\mathrm{Ta}-12.95$ & Ti-20.61 & $\mathrm{Zr}-5.3$ \\
\hline CrNbTiVZr & $\mathrm{Cr}-20.2$ & $\mathrm{Nb}-20$ & $\mathrm{Ti}-19.96$ & $V-19.96$ & $\mathrm{Zr}-6.57$ & \\
\hline TiNbMoTaW & $\mathrm{Ti}-18.87$ & $\mathrm{Nb}-21.6$ & Mo -21.8 & $\mathrm{Ta}-18.95$ & $\mathrm{~W}-18.78$ & \\
\hline $\mathrm{W}_{0.33} \mathrm{NbMoTa}$ & $\mathrm{W}-12.42$ & $\mathrm{Nb}-27.4$ & Mo -30.01 & $\mathrm{Ta}-30.17$ & & \\
\hline CrMoNbTaVW & $\mathrm{Cr}-27.05$ & Mo -13.68 & $\mathrm{Nb}-13.63$ & $\mathrm{Ta}-13.64$ & $V-15.18$ & $\mathrm{~W}-16.81$ \\
\hline MoNbHfZrTi & Mo -19.58 & $\mathrm{Nb}-20.51$ & Hf - 20,42 & $\mathrm{Zr}-20.1$ & $\mathrm{Ti}-19.39$ & \\
\hline $\mathrm{NbCrMo}_{0.5} \mathrm{Ta}_{0.5} \mathrm{TiZr}$ & $\mathrm{Nb}-21.84$ & $\mathrm{Cr}-18.39$ & Mo -10.04 & $\mathrm{Ta}-11.86$ & $\mathrm{Ti}-19.4$ & $\mathrm{Zr}-18.48$ \\
\hline
\end{tabular}

A comparative analysis of the hardness of HEAs and several common alloys exhibits a great variation in hardness (Figure 2) [34]. As the hatched area shows, there are two solutions to increase the hardness, either by changing the concentration of one or more chemical elements or by applying thermo-mechanical treatments. As it is noticed in Figure 2, the AlCrFeMnNi and AlCrFeMoNi alloys have a significant higher hardness than the ordinary alloys [35].

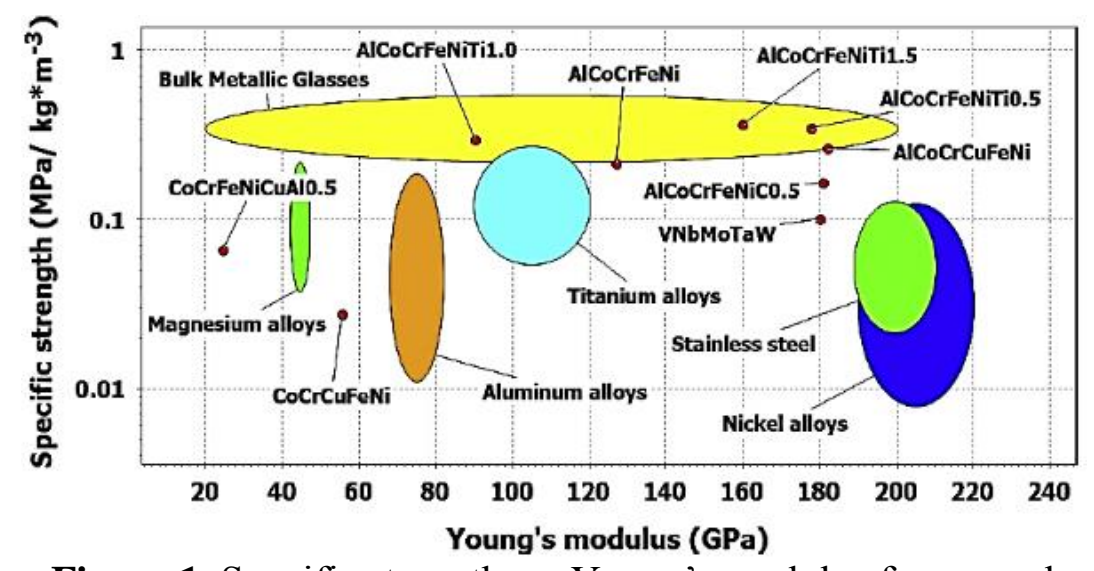

Figure 1. Specific strength vs. Young's modulus for several HEAs and conventional alloys [34] 


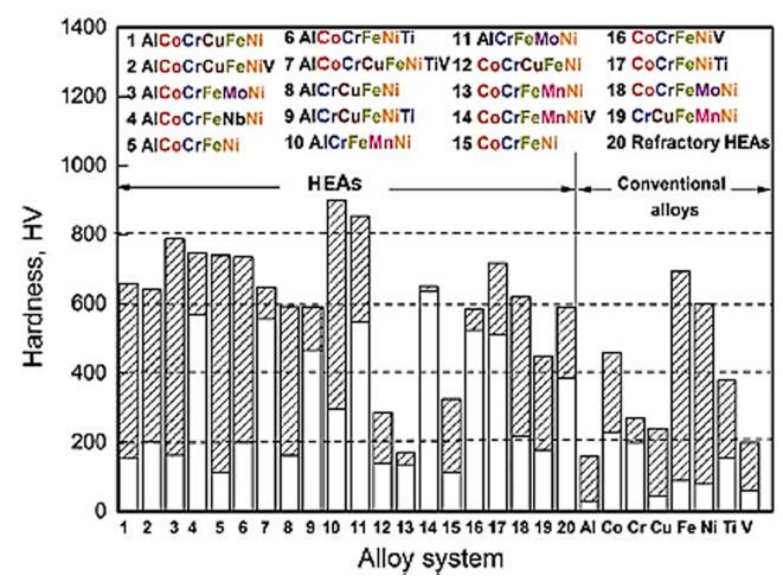

Figure 2. Hardness of HEAs and of several conventional alloys [35]

One of the most important features of HEAs is the ability to keep their mechanical properties at high temperatures. Figure $3 a$ displays the yield strength-temperature curve for the Inconel 718 and Haynes 230 nickel alloys, employed in high-temperature applications, and for some HEAs. By comparison, the MoNbTaVW and MoNbTaW alloys preserve better the yield strength values at high temperatures $\left(1600^{\circ} \mathrm{C}\right)$ than the $\mathrm{Ni}$ alloys. Figure $3 \mathrm{~b}, \mathrm{c}$, and $\mathrm{d}$ exhibit the hardness vs. temperature for some HEAs, as well as the influence of the alloying element percentage on the variation curve. It notices that increasing the $\mathrm{Al}, \mathrm{Cr}$ and Co percentage, the effect on the hardness is different. While a higher concentration of $\mathrm{Al}$ and $\mathrm{Cr}$ increases the hardness, a higher concentration of Co leads to hardness decrease [35]. Furthermore, the HEAs preserve their mechanical properties not only at high temperatures but also at low temperatures. For instance, the CoCrFeMnNi alloy, whose stress-strain diagram for different temperatures is shown in Figure 3e, has outstanding mechanical characteristics at temperatures of $-200^{\circ} \mathrm{C}$ [36]. This paper presents a review focused on the weldability and behaviour of $\mathrm{CoCrFeMnNi}$, AlCoCrCuFeNi, AlCrFeCoNi, and $\mathrm{CoCrFeNi}$ alloys during Friction Stir Welding (FSW), Electron Beam Welding (EBW), LASER Beam Welding (LBW), and Tungsten Inert Gas (TIG). Original results related to the weldability and behaviour of new AlCrFeMnNi alloys developed and subjected to Shielded Metal Arc Welding, as a technical solution for performing morphofunctional structures used in the military field, are presented and discussed, too.

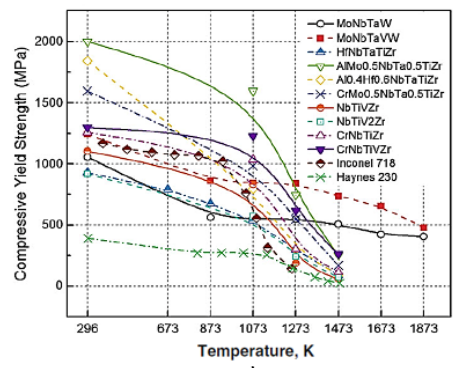

a)

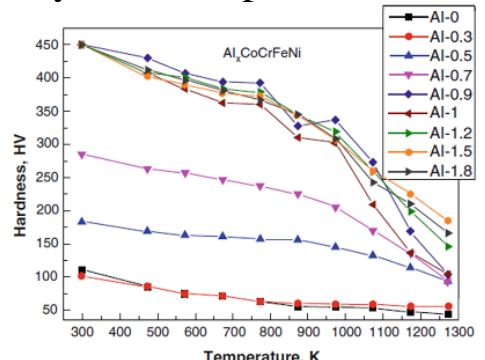

b)

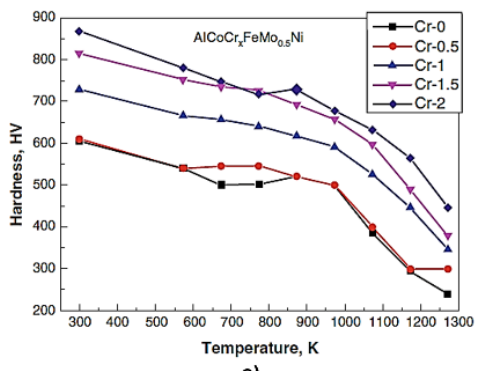

c)

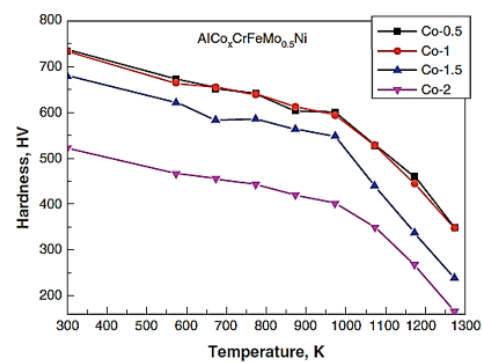

d)

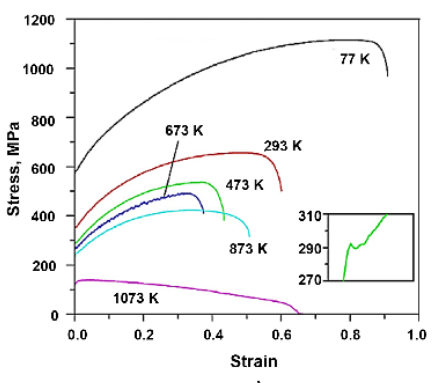

e)

Figure 3. HEA's mechanical properties vs. temperature $[35,36]$ 


\section{Results and discussions}

This study addresses the current state of the HEAs weldability and the identification of the optimal process parameters which can be employed to perform quality welded joints. The discussion is focused on the analysis of the welding process effects that caused mechanical and metallurgical modifications in HEAs welded joints.

\subsection{CoCrFeMnNi High Entropy Alloy}

Due to its mechanical properties, the CoCrFeMnNi alloy has been found as a promising material that can be successfully employed for cryogenic applications. At room temperature, the yield strength of this alloy is relatively low, being approximately $200 \mathrm{MPa}[37,38]$. Applying certain thermomechanical treatments, the mechanical properties can be greatly improved. Thus, after treatment, the yield strength can reach up to $1834 \mathrm{MPa}$, the ultimate tensile strength up to $2069 \mathrm{MPa}$, uniform elongation of $1.4 \%$ and total elongation of $7.4 \%$ at room temperature. Moreover, at $-200^{\circ} \mathrm{C}$ temperature, this alloy has $1442 \mathrm{MPa}$ yield strength, $1596 \mathrm{MPa}$ ultimate tensile strength, $1.3 \%$ uniform elongation and $10.4 \%$ total elongation [37]. Wu Z. et al. investigated the weldability of the CrMnFeCoNi alloy, using EB and GTA processes for butt welding of plates with $1.6 \mathrm{~mm}$ thickness. The main EB process parameters applied by the authors are voltage of $125 \mathrm{kV}$, amperage of $2.2 \mathrm{~mA}$ and welding speed of $38 \mathrm{~mm} / \mathrm{min}$. The tensile testing performed at both room temperature and at negative temperature showed that the welded samples retained the tensile strength of the base material, but the ductility decreased by $30 \%$ (Figure 4a) [39, 40]. The microstructural and spectral analysis showed that a grain elongation and a depletion of Mn occurred in the fusion zone (Figure 4b) [39], [40]. The concentration of Mn decreased from $20 \%$ percentage in the base material (BM) to $13 \%$ in the dendritic zones and $16.8 \%$ in the interdendritic areas. The GTA process parameters used for performing the samples are amperage of $75 \mathrm{~A}$, voltage of $8.4 \mathrm{~V}$ and a welding speed of $25 \mathrm{~mm} / \mathrm{min}$. From the analysis of the joint macrostructure, it was found that the fusion zone has a columnar structure with large grains formed from the fusion line to the weld centre (Figure 4c). Comparing the mechanical properties of the welded joint and of the base material, the tensile testing, performed at both $20^{\circ} \mathrm{C}$ and at $-200^{\circ} \mathrm{C}$ temperatures, revealed an increase of $10 \%$ of the yield strength, a decrease of $20 \%$ of the tensile strength, and a decrease by half of the welded joint ductility. Unlike EB welding, no depletion of $\mathrm{Mn}$ has been found in the $\mathrm{CoCrFeMnNi}$ welded joint performed by GTA welding (Figure 4c) [39]. The researchers have concluded that the experimental results obtained by GTA welding can be improved if measures to reduce the amount of oxygen in the weld pool area and the adjacent area are applied.

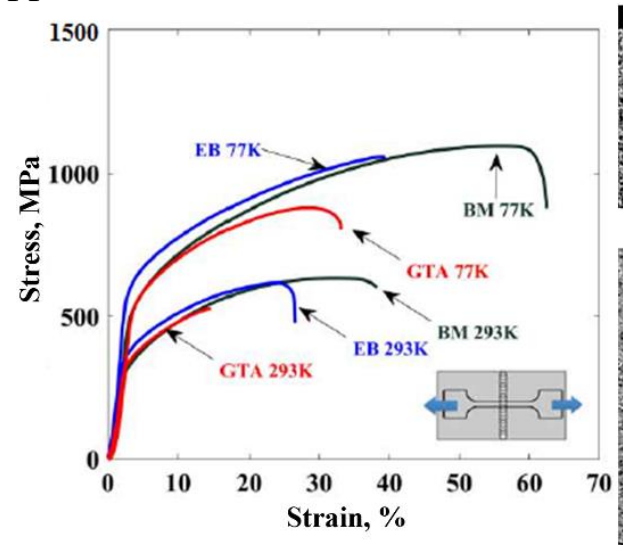

a)

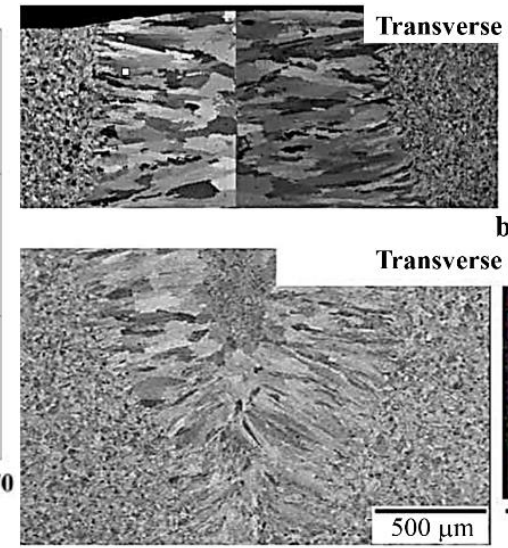

c)

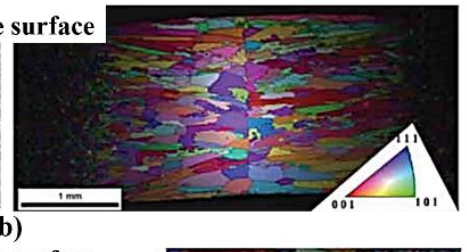

surface

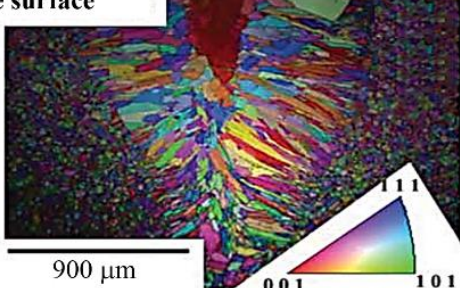

Figure 4. Welded joints of CrMnFeCoNi alloy: a) stress-strain curve; b) macrostructure of the EB welded joint; c) macrostructure of the GTA welded joint [39, 40] 
Kashaev N. et al. studied the weldability of the CoCrFeNiMn alloy during the LBW process. The plates, having $15 \times 15 \times 2[\mathrm{~mm}]$ dimensions, were joined with the following welding parameters: laser beam power of $2 \mathrm{~kW}$, beam diameter of $300 \mu \mathrm{m}$, a focal length of $0 \mathrm{~mm}$, and welding speed from 3 to $6 \mathrm{~m} / \mathrm{min}$. For the welding speed below $3 \mathrm{~m} / \mathrm{min}$, the authors reported a significant increase in the thickness of the weld and for a value over $6 \mathrm{~m} / \mathrm{min}$ an incomplete penetration has been observed. A right weld bead geometry and an optimal cylindrical "I" shape of the weld, which provides better tensile properties, were achieved for the welding speed values of 4 and $5 \mathrm{~m} / \mathrm{min}$. No major differences in terms of microstructure and grain orientation have been noticed between the base material, Heat Affected Zone (HAZ) and weld zone. The authors reported a significant increase of the microhardness in the fusion zone that is caused by the precipitation of B2 microparticles whose diameter is about 5 $\mu \mathrm{m}$ (Figure 5a, b) [41, 42].
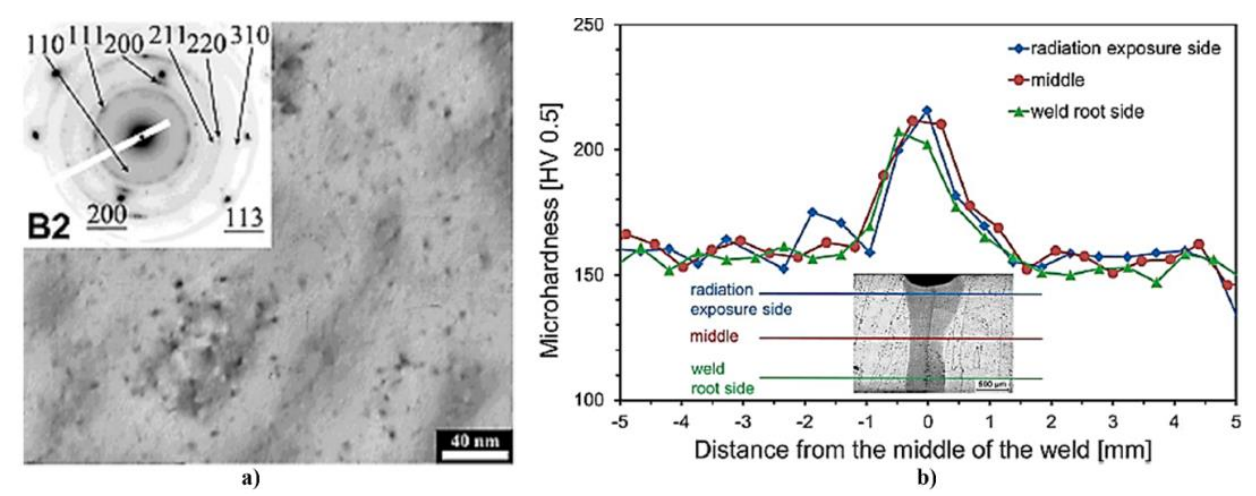

Figure 5. CoCrFeNiMn alloy welded by Laser Beam procedure:

a) B2 microparticles precipitation in weld area; b) micro-hardness profile [41, 42]

The weldability of the CoCrFeNiMn alloy joined by LBW was also studied by Nam H. et al. who used plates of 100x20x1.5 [mm] dimensions, obtained by casting and by rolling. The samples were performed with the following process parameters: laser beam power of $2 \mathrm{~kW}$, beam diameter of $300 \mu \mathrm{m}$, a focal length of $304 \mathrm{~mm}$, and welding speed of 6,8 and $10 \mathrm{~m} / \mathrm{min}$. It was achieved full penetration, but shrinkage voids have been noticed in the interdendritic region which were developed when the welding speed was $6 \mathrm{~m} / \mathrm{min}$. If the welding speed was increased to $10 \mathrm{~m} / \mathrm{min}$, the shrinkage voids disappeared, but the penetration in the weld was incomplete [43]. It was found that the welding speed did not significantly affect the mechanical characteristics of the welded joints carried out by LBW (Figure 6a) [43]. The micro-hardness analysis revealed a significant increase in the fusion zone for the cast alloys and a minor increase for the rolled alloys (Figure 6b) [43]. The increase of the micro-hardness in the cast alloy was attributed to the fact that the dendritic arm spacing was 200 times smaller in the fusion zone than in the base material, while in the case of the rolled alloys the dendritic arm spacing was similar in both zones [43, 45]. Due to the low heat input and concentrated welding source, no significant differences related to the metallurgical structure were identified between base material, HAZ, and weld zone (Figure 6c, d) [43, 44]. Based on the analysis of process parameters used by Kashev et al., on the one hand, and the parameters applied by Nam et al., on the other hand, it can be concluded that increasing the focal length of the laser beam from 0 to $304 \mathrm{~mm}$, the welding speed may be increased, too. In both cases, the effects generated by the welding process in the welded joints seem to be similar. 


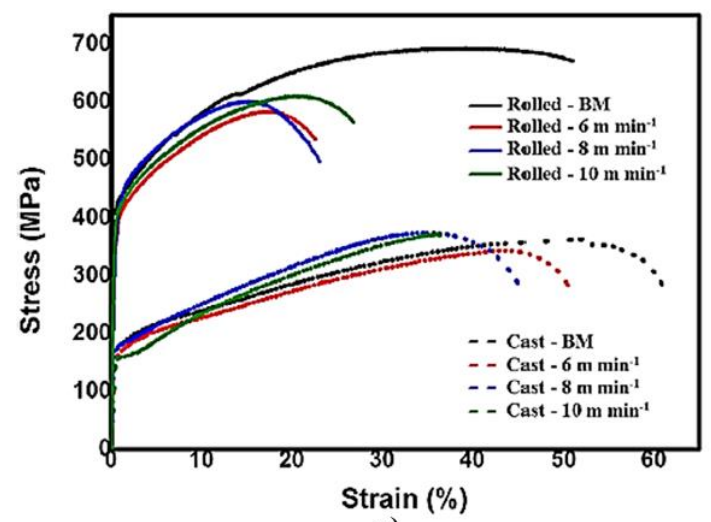

a)

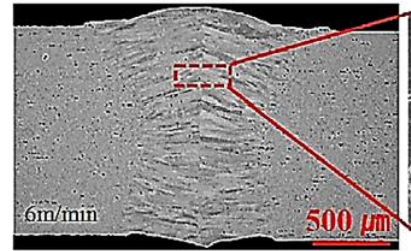

c)

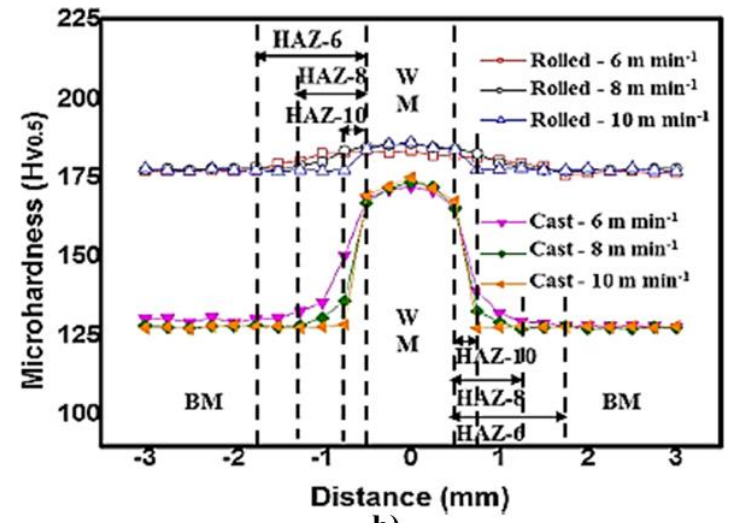

b)

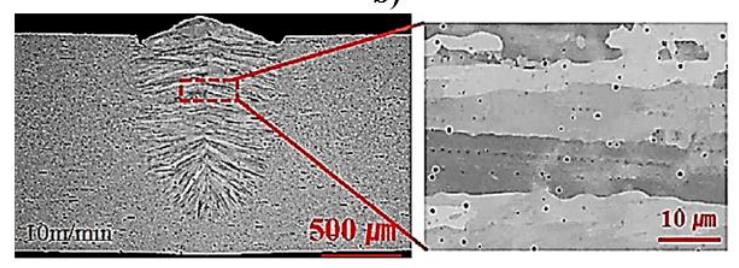

d)

Figure 6. CoCrFeNiMn alloy welded by Laser Beam procedure: a) stress-strain curve; b) micro-hardness profile; c), d) macro and microstructure (welding speed of $6 \mathrm{~m} / \mathrm{min}$ and $10 \mathrm{~m} / \mathrm{min}$, respectively) [43]

Jo M. G. et al. studied the weldability of CrMnFeCoNi alloy, employing LBW and FSW processes. The experimental tests by LBW have been done on plates with $60 \times 55 \times 1$ [mm] dimensions, using a copper backing plate and argon as shielding gas. A laser beam power of $9 \mathrm{~kW}$, beam diameter of 200 $\mu \mathrm{m}$, focal length of $450 \mathrm{~mm}$ and welding speed of $9 \mathrm{~m} / \mathrm{min}$ were applied for achieving the samples. The tensile testing results showed that the yield strength of the welded joint is comparable to that of the base material, but the ductility has decreased by $16 \%$ because of the inclusions of $\mathrm{MgO}$ and $\mathrm{MgSO}_{4}$. A columnar structure was formed in the fusion zone, the dendrites growing from the fusion zone line towards the weld centre [46]. An increase of approximately $30 \%$ of the hardness was noticed in the weld, this increase being attributed to the finer dendrite arm spacing in the fusion zone in comparison with that of the base material, as well as to a possible chemical composition fluctuation (Figure 7) [46, 47].
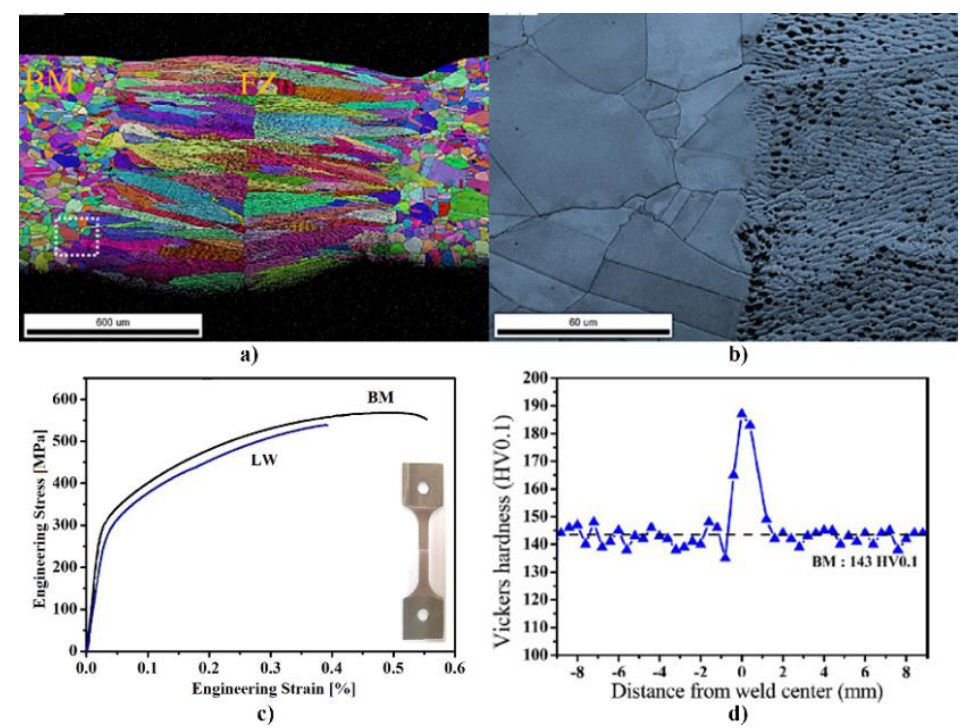

Figure 7. CrMnFeCoNi alloy welded by Laser Beam procedure:

a) macrostructure; b) microstructure; c) stress-strain curve; d) hardness [46] 
Another programme experimental developed by the authors was focused on FSW of CrMnFeCoNi alloy plates with $60 \times 55 \times 2[\mathrm{~mm}]$ dimensions. The samples were carried out by using the welding speed of $150 \mathrm{~mm} / \mathrm{min}$ and the rotational speed of $600 \mathrm{rpm}$. The geometry of the rotating element is characterised by $12 \mathrm{~mm}$ shoulder diameter, $4 \mathrm{~mm}$ pin diameter, $1.85 \mathrm{~mm}$ length, and a tilt of $3^{\circ}$. After performing the tensile testing, it was observed a higher yield strength $(296 \mathrm{MPa})$ of the welded joint in comparison with that of the base material (272 MPa), while the ductility has decreased by $9 \%$ (Figure 8) [46]. Due to the dynamic recrystallization phenomenon, the grain size decreased significantly from $70 \mu \mathrm{m}$ in the BM to $5 \mu \mathrm{m}$ in the stir zone (SZ). Consequently, the hardness in the SZ increased from $144 \mathrm{HV}$ in BM to $190 \mathrm{HV}$ in the shoulder action area and $220 \mathrm{HV}$ in the pin tool action area (Figure 8) [46].
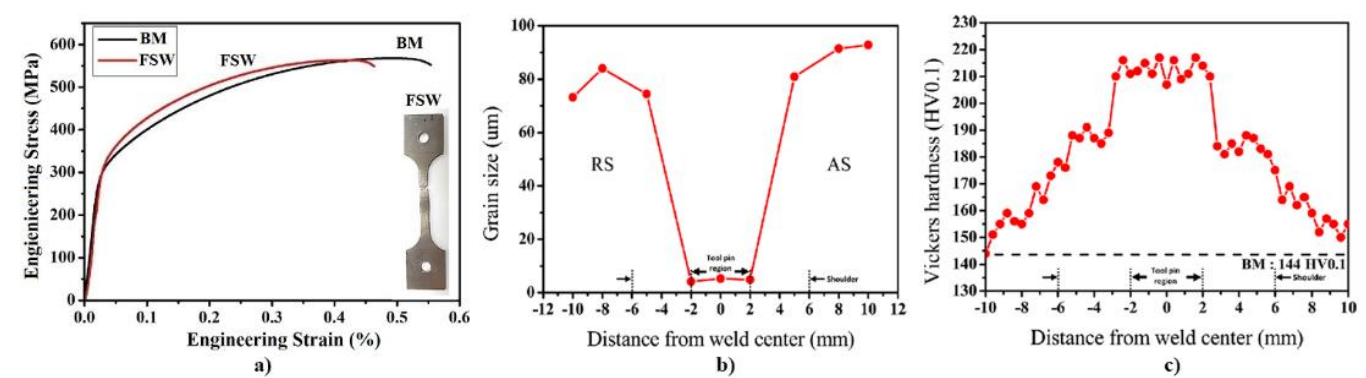

Figure 8. CrMnFeCoNi alloy welded by FSW procedure:

a) stress-strain curve; b) grain size; c) hardness [46]

Shaysultanov D. et al. studied the weldability of CoCrFeNiMn alloy, microalloyed with C. The laminated plates with $70 \times 40 \times 2[\mathrm{~mm}]$ dimensions were double-sided welded by FSW process. The welding parameters were set as follows: welding speed of $30 \mathrm{~mm} / \mathrm{min}$, rotational speed of $1000 \mathrm{rpm}$, and a loading force of $11.1 \mathrm{kN}$. The diameter of the rotating element was $12.5 \mathrm{~mm}$, the tool pin has a length of $1.5 \mathrm{~mm}$ and was tilted at an angle of $2.5^{\circ}$. Following the microstructure analysis, a decrease in grain sizes, from $9.2 \mu \mathrm{m}$ to $4.6 \mu \mathrm{m}$, was noticed in the SZ (Figure 9a) [48]. Besides, an increase in the volume of the $\mathrm{M}_{23} \mathrm{C}_{6}$ carbides was detected and that determined a significant increase by approximately $40 \mathrm{HV}$ of the hardness, and by about $200 \mathrm{MPa}$ of the ultimate tensile strength (Figure $9 \mathrm{~b}, \mathrm{c})$ [48]. Moreover, the presence of $\mathrm{W}$ was observed in the SZ that was attributed to the wear of the rotating tool [48].

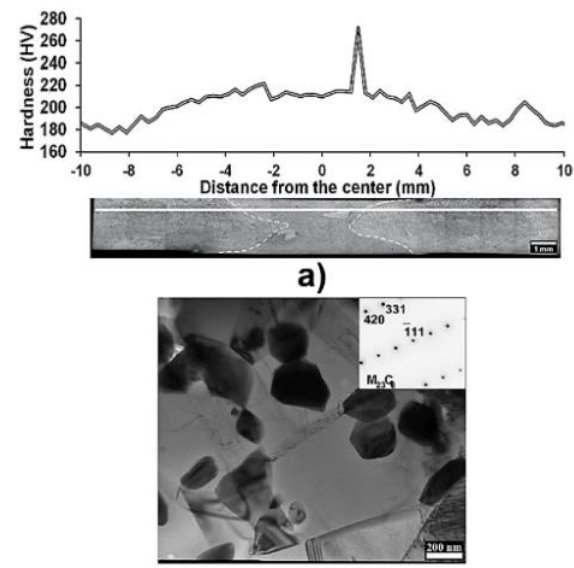

b)

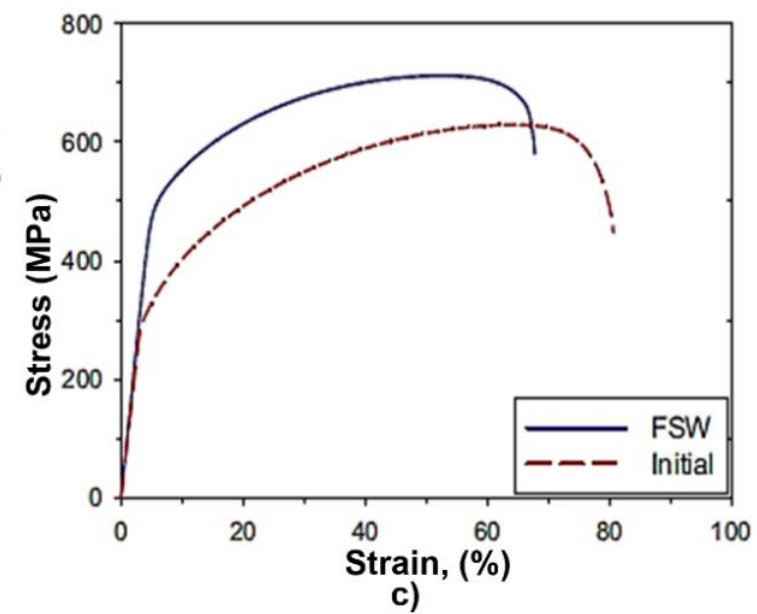

Figure 9. CoCrFeNiMn alloy welded by double-sided FSW procedure:

a) macrostructure and hardness profile; b) M23C6 carbides in the SZ;

b) stress-strain curve [48] 


\subsection{AlCoCrCuFeNi High Entropy Alloy}

The mechanical properties of AlCoCrCuFeNi HEA make it suitable for high-temperature applications. The yield strength can reach $1750 \mathrm{MPa}$ and the compressive strength can be improved to $2100 \mathrm{MPa}$ by applying thermo-mechanical treatments [49]. As Kuznetsov A. V. et. Al. reported, this HEA has $542 \mathrm{MPa}$ tensile strength and elongation of $0.4 \%$ at temperature of $600^{\circ} \mathrm{C}, 350 \mathrm{MPa}$ tensile strength and 4.7 elongation at temperature of $700^{\circ} \mathrm{C}$, and $161 \mathrm{MPa}$ tensile strength and $12.1 \%$ elongation at temperature of $800^{\circ} \mathrm{C}$ [50].

Martin A. et al. studied the behaviour of $\mathrm{Al}_{0.5} \mathrm{CoCrCu}_{0.1} \mathrm{FeNi}$ alloy subjected to Gas Tungsten Arc Welding (GTAW) and pulsed LBW. Heat-treated plates, having $63 \times 3 \times 3[\mathrm{~mm}]$ dimensions, were joined by using $95 \mathrm{~A}$ amperage, $11 \mathrm{~V}$ voltage and $4.3 \mathrm{~mm} / \mathrm{s}$ welding speed. A wide HAZ of $1.5 \mathrm{~mm}$ width was formed, but no defect was detected in the welded joint (Figure 10a) [51]. Also, the authors investigated the weldability of $\mathrm{Al}_{0.5} \mathrm{CoCrCu}_{0.1} \mathrm{FeNi}$ alloy on heat-treated and hot-rolled plates (Figure $10 \mathrm{~b})$ which were butt-welded in two passes with $100 \mathrm{~A}$ amperage, $10.5 \mathrm{~V}$ voltage and welding speed of $3 \mathrm{~mm} / \mathrm{s}$. Following the joint microstructure, the authors reported the existence of a gap of $0.24 \mathrm{~mm}$ size between passes, a narrow HAZ with a $0.5 \mathrm{~mm}$ width and a significant decrease of the hardness in the fusion zone (Figure 10f). Besides, a crack that is generated in the alloys with face-centred cubic (FCC) structure by welding, was observed at the beginning of the second pass. To avoid the development of this type of defects, technical measures as reducing the welding speed and using the technological plates have to be considered when the welding regime is designed [51]. Martin A. et al. investigated the weldability of $\mathrm{Al}_{0.5} \mathrm{CoCrCu}_{0.1} \mathrm{FeNi}$ HEA during pulsed LBW on three samples joined by three welding regimes. The first sample was welded with $1 \mathrm{~kW}$ beam power and $1.66 \mathrm{~mm} / \mathrm{s}$ welding speed, the second sample with $5 \mathrm{~kW}$ beam power and $0.78 \mathrm{~mm} / \mathrm{s}$ welding speed and the third sample was made using $1 \mathrm{~kW}$ beam power and $2.5 \mathrm{~mm} / \mathrm{s}$ welding speed. Using the "keyhole" welding technique, a greater penetration was achieved in the first welded sample, but some porosity and solidification cracks caused by high cooling rates have occurred in the fusion zone (Figure 10c) [51] [52]. To achieve samples free of defects, some adjustments of the process parameters were made. The result was an increase of the width to depth ratio of the weld for the second and the third specimens (Figure 10d, e). It was noticed that at higher beam power combined with a slower welding speed lead to greater penetration and larger width of the fusion zone in comparison with the weld geometry obtained with lower beam power and faster welding speed. Comparing the micro-hardness values measured in the weld area, Martin A. C. et al. reported higher hardness in the samples performed by LBW than in the case of GTAW and that can be explained by due to the more refined grains resulted in the LBW joints (Figure 10f) [51].
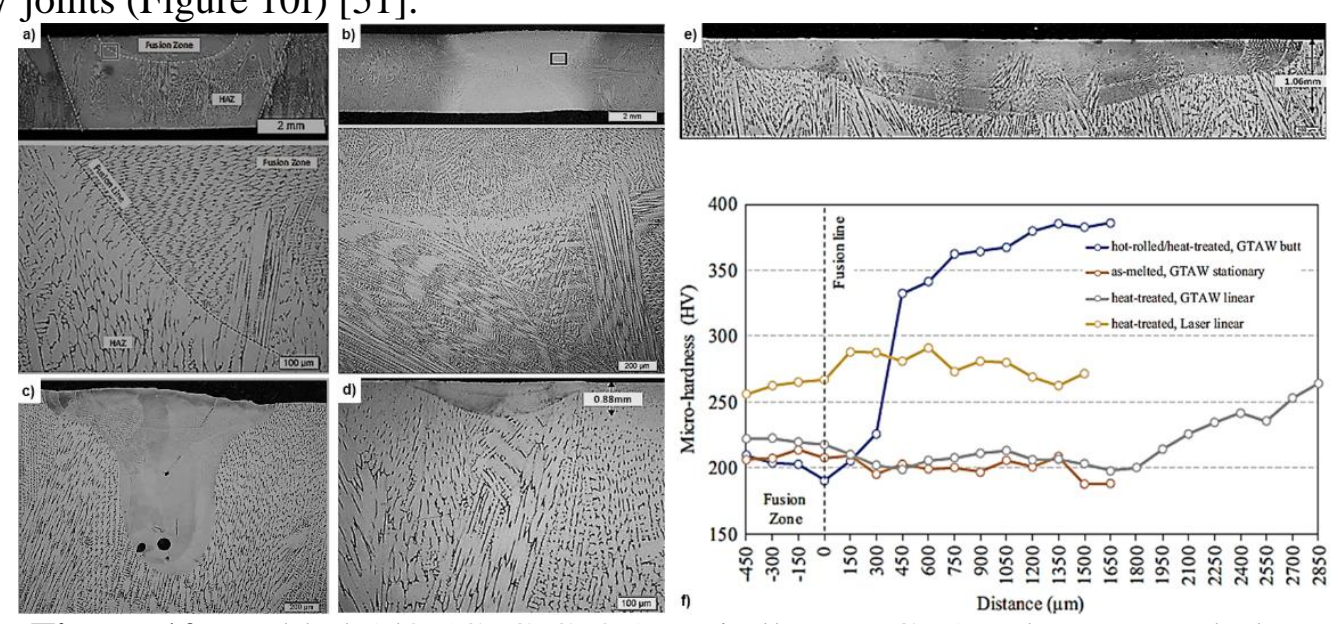

Figure 10. Welded Al0.5CoCrCu0.1FeNi alloy: a) GTAW heat-treated plate;

c) GTAW heat-treated and hot-rolled plate; c), d), e) LBW sample; f) micro-hardness

d) profile in GTAW and LBW joints [51] 


\subsection{AlCrFeCoNi High Entropy Alloy}

As Munitz A. et al. reported, the mechanical properties of this HEA can be greatly improved by thermo-mechanical treatments, resulting an alloy with $6 \mathrm{GPa}$ hardness, $1450 \mathrm{MPa}$ compressive yield stress, $2500 \mathrm{MPa}$ compressive ultimate tensile strength, and fracture strain of $20.1 \%$ [53]. Moreover, this alloy displays great mechanical characteristics at cryogenic temperatures of $-200^{\circ} \mathrm{C}$, being characterised by $1880 \mathrm{MPa}$ yield strength, $3550 \mathrm{MPa}$ ultimate yield strength, and fracture strain of $14.3 \%$ elongation [54] [55]. Wang W. R. et al. investigated the behaviour of AlCrFeCoNi alloy at high temperatures, reporting hardness values of approximately $400 \mathrm{kgf} / \mathrm{mm}^{2}$ at $400^{\circ} \mathrm{C}, 350 \mathrm{kgf} / \mathrm{mm}^{2}$ at $600^{\circ} \mathrm{C}, 275 \mathrm{kgf} / \mathrm{mm}^{2}$ at $800^{\circ} \mathrm{C}$, and $275 \mathrm{kgf} / \mathrm{mm}^{2}$ at $1000^{\circ} \mathrm{C}$ [56]. Sokkalingam R. et al. studied the weldability of the $\mathrm{Al}_{0.5} \mathrm{CoCrFeNi}$ alloy, using plates of $30 \times 30 \times 2.5[\mathrm{~mm}]$ dimensions, which were welded by TIG welding procedure. The process parameters were the current of $40 \mathrm{~A}$, voltage of $12 \mathrm{~V}$ and welding speed of $80 \mathrm{~mm} / \mathrm{min}$. It was observed the formation of a narrow HAZ, in which the grains near the fusion line had doubled the size, comparing to the initial grains whose size was approximately $60 \mu \mathrm{m}$. In the fusion zone, fine and elongated grains with diameters ranges from 8 to $12 \mu \mathrm{m}$ and length from 80 to $120 \mu \mathrm{m}$ were developed. Each grain from the HAZ acted as a nucleation site for ten or more grains that were developed in the fusion-zone. The tensile testing showed a decrease in the mechanical strength of the welded joint by $6.4 \%$ and in the ductility by $16.5 \%$. The hardness measurement revealed a decrease of hardness in the weld and $\mathrm{HAZ}$ from $285 \mathrm{HV}_{0.05}$ in $\mathrm{BM}$ to $225 \mathrm{HV}_{0.05}$ found in the weld centre (Figure 11) [57].

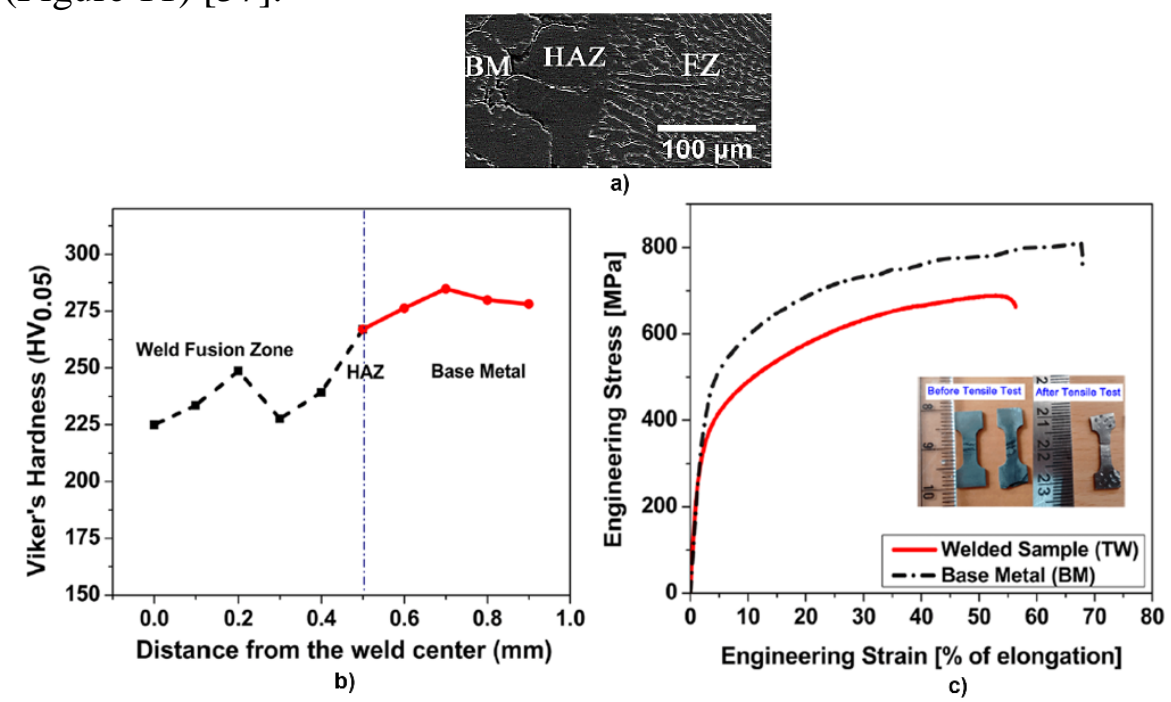

Figure 11. TIG welded $\mathrm{Al} 0,5 \mathrm{CoCrFeNi}$ alloy: a) microstructure;

b) hardness; c) stress-strain curve [57]

Also, Sokkalingam R. et al. investigated the weldability of the $\mathrm{Al}_{0.5} \mathrm{CoCrFeNi}$ alloy on plates of 1 mm thickness during the LBW process with a laser beam power of $1.5 \mathrm{~kW}$ and welding speed of 600 $\mathrm{mm} / \mathrm{min}$. Due to the reduced thickness of the plates and to the low laser beam power, which caused the fast heating and cooling of the welded joint, a refinement of the grains developed in the weld has noticed (Fig. 12) [58, 59]. The spectral analysis showed no significant segregation of chemical elements in the fusion zone, excepting $\mathrm{Al}$ and Ni. Because of this interdendritic separation, a decrease of hardness in the weld has been observed as figure 12 lays out [58]. 


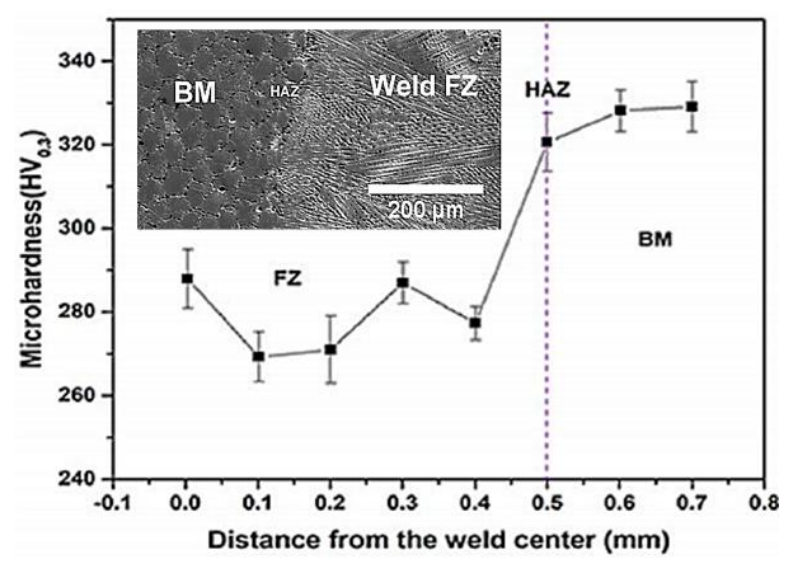

Figure 12. Laser Beam welded Al0.5CoCrFeNi alloy: microstructure and micro-hardness [58], [59]

The weldability of $\mathrm{Al}_{\mathrm{x}} \mathrm{CoCrFeNi}$ alloy, where $\mathrm{x}=0.6$ and $\mathrm{x}=0.8$, during EBW has been analysed by Nahmany M. et al., too. Two samples were carried out with similar welding parameters $(1 \ldots 4 \mathrm{~mA}$ amperage, $60 \mathrm{kV}$ voltage, $1 \mathrm{~m} / \mathrm{min}$ welding speed, and the beam diameter of $0.3-0.5 \mathrm{~mm}$ ). Based on the microstructural analysis, a decrease of the size of the dendrites, from $60 \mu \mathrm{m}$ in the base material to $2 \mu \mathrm{m}$ in the weld area, was found. Besides, the hardness increased by $28 \%$ in the alloy with $6 \% \mathrm{Al}$ (P3) and by $34 \%$ in the alloy with $8 \% \mathrm{Al}(\mathrm{P} 2)$. Figure 13 shows the microstructure, the $\mathrm{HV}_{0.1}$ microhardness profile for both samples and the macrostructure of welds achieved for the welding current ranging from $1 \mathrm{~mA}$ to $4 \mathrm{~mA}$ [60]. It is obviously that increasing the amperage, the weld depth increases as well (Figure $13 \mathrm{c}, \mathrm{d}$ ).

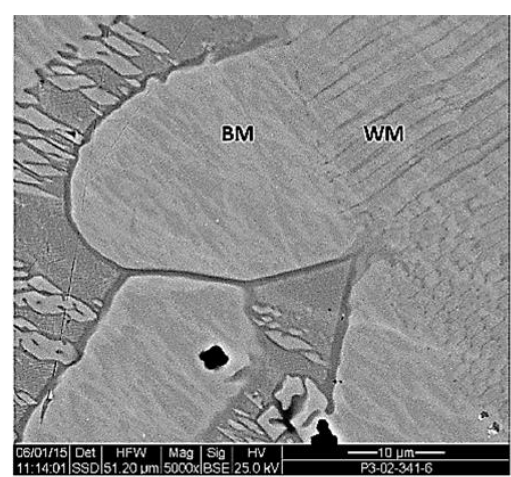

a)

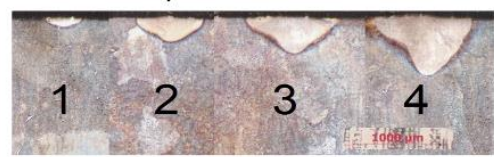

c)

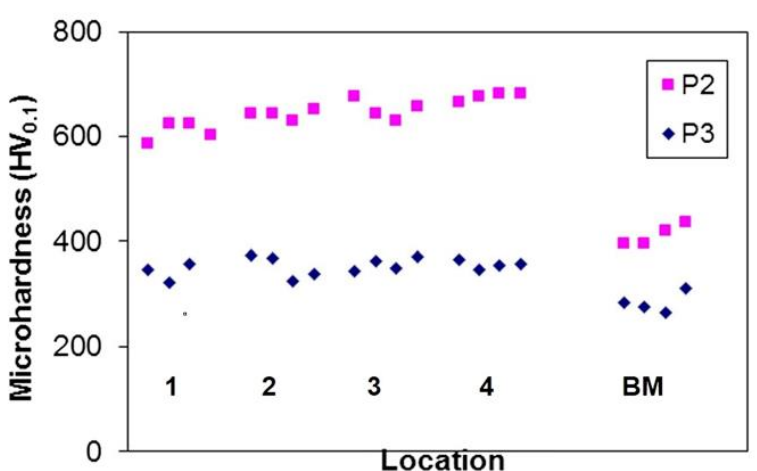

b)

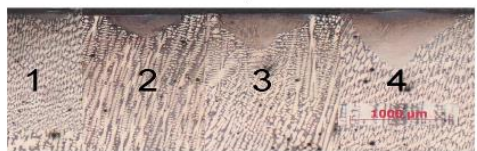

d)

Figure 13. Electron Beam welded $\mathrm{AlxCrFeCoNi}$ alloy: a) microstructure;

b) micro-hardness; c) macrostructure of the $8 \%$ Al welded alloy; d) macrostructure of the $6 \% \mathrm{Al}$ welded alloy [60]

Another welding technique that was employed by Zhu Z.G. et al. in the study AlCrFeCoNi alloy weldability was FSW. The CoCrFeNiAl 0.3 alloy plates of 30x10x2 [mm] dimensions were joined, applying the welding speed of $30 \mathrm{~mm} / \mathrm{min}$ and $50 \mathrm{~mm} / \mathrm{min}$, a rotational speed of $400 \mathrm{rpm}$ and a load force of $14.7 \mathrm{kN}$. The rotating element had the shoulder diameter of $12 \mathrm{~mm}$, pin diameter of $4 \mathrm{~mm}$ and length of $1.8 \mathrm{~mm}$. The microstructure analysis revealed an increase of the grains from the initial size of $111 \mu \mathrm{m}$ in the BM to $132 \mu \mathrm{m}$ in the Thermo-Mechanically Affected Zone (TMAZ) caused by diffusion 
in this area of heat developed during welding. On the other hand, due to the dynamic recrystallization phenomenon, fine grains, whose size is $2.79 \mu \mathrm{m}$ in the sample performed with the welding speed of 50 $\mathrm{mm} / \mathrm{min}$ and $2.66 \mu \mathrm{m}$ in the sample performed with the welding speed of $30 \mathrm{~mm} / \mathrm{min}$, were observed in the Stir Zone (SZ). Consequently, higher values of hardness have been found in the SZ, as Figure 14 shows [61].

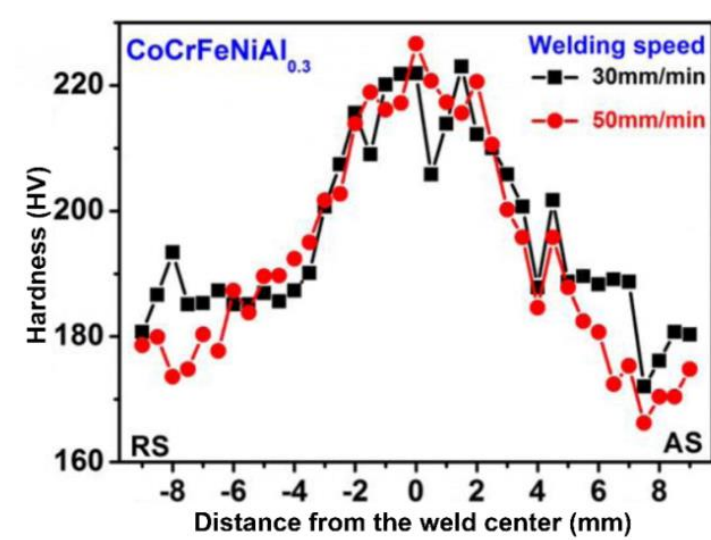

a)

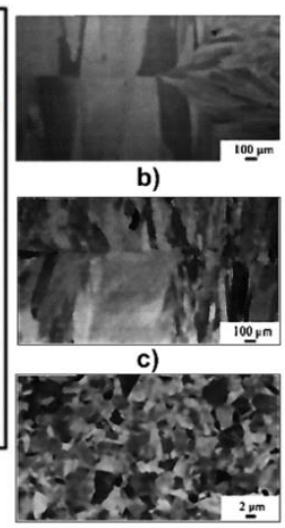

d)

Figure 14. FSW welded CoCrFeNiAl0.3 alloy: a) hardness; microstructure in b) BM; c) TMAZ; d) SZ [61]

\subsection{CoCrFeNi High Entropy Alloy}

$\mathrm{CoCrFeNi}$ alloy is another HEA which is suitable for cryogenic applications. After the alloy undergoes a thermo-mechanical treatment, good mechanical properties, such as $680 \mathrm{MPa}$ yield strength, $1260 \mathrm{MPa}$ ultimate yield strength and a $60 \%$ elongation to failure, are determined at temperature of $-270^{\circ} \mathrm{C}$ [62]. Zhu Z.G. et al. studied the weldability of $\mathrm{Co}_{16} \mathrm{Fe}_{28} \mathrm{Ni}_{28} \mathrm{Cr}_{28}$ alloy, using plates of 30x10x2 [mm] dimensions which were welded by FSW. The welding process parameters applied to achieve the samples were a rotational speed of $400 \mathrm{rpm}$, a welding speed of $30 \mathrm{~mm} / \mathrm{min}$ and $50 \mathrm{~mm} / \mathrm{min}$, and a load force of $14.7 \mathrm{kN}$. The rotating element had the shoulder diameter of $12 \mathrm{~mm}$, pin diameter of $4 \mathrm{~mm}$ and length of $1.8 \mathrm{~mm}$. Similar to the previous case, the most refined grains have been found in SZ. Besides, due to the larger strain rate and to the reduction of heat amount generated in the SZ and, consequently, due to the decrease of the maximum temperature reached in this zone, the grain size is smaller when the welding speed increases. Also, another effect of refining the grains in SZ, an increase of hardness from $174 \mathrm{HV}$ in BM to $250 \mathrm{HV}$ in SZ was noticed. In both studies, the presence of the chemical element W was found in the SZ caused by the rotating tool wear (Figure 15) [63].

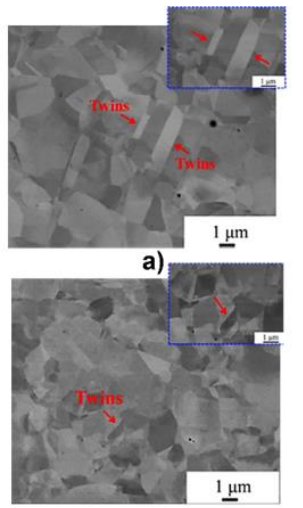

b)

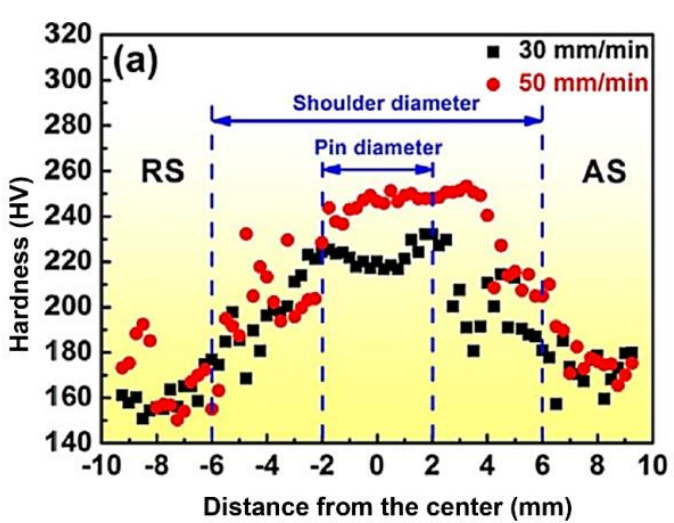

c)

Figure 15. FSW welded $\mathrm{Co}_{16} \mathrm{Fe}_{28} \mathrm{Ni}_{28} \mathrm{Cr}_{28}$ alloy: a) microstructure welding speed of $30 \mathrm{~mm} / \mathrm{m}$ ); b) microstructure (welding speed of $50 \mathrm{~mm} / \mathrm{min}$ );

c) hardness [63] 


\subsection{AlCrFeMnNi High Entropy Alloy}

Based on the state-of-the-art focused on HEAs materials behaviour during welding, the authors designed and applied a new procedure for welding HEA. Plates of AlxCrFeMnNi HEA ( $\mathrm{x}=0.8)$ and AlCrFeMnNix HEA $(\mathrm{x}=1.4)$, having $6 \mathrm{~mm}$ thickness, without edges machining, were joined by SMAW technique. The electrode Bohler FOX CN 22/9 N with diameter of $4 \mathrm{~mm}$ and the chemical composition consisting of $\mathrm{C}=0.03 \mathrm{wt} . \% ; \mathrm{Mn}=0.8 \mathrm{wt} . \% ; \mathrm{Cr}=23 \mathrm{wt} . \% ; \mathrm{Ni}=9.0 \mathrm{wt} . \% ; \mathrm{Mo}=3.2 \mathrm{wt} . \%$, and $\mathrm{N}=0.17 \mathrm{wt} . \%$ was selected to be employed for welding the new HEAs. The main process parameters were $120 \mathrm{~A}$ amperage, $34 \mathrm{~V}$ voltage, and welding speed of $12 \mathrm{~cm} / \mathrm{min}$. The microstructural analysis of the $\mathrm{Al}_{\mathrm{x}} \mathrm{CrFeMnNi}$ alloy joint showed the presence of crack in HAZ (Figure 16a), the reason being the high brittleness of the material. Figure $16 \mathrm{~b}$ reveals the brittle fracture mechanism which is responsible for the fast propagation of crack without apparent plastic deformation before fracture. The experiments demonstrated that the other HEA (AlCrFeMnNix) has good weldability and compatibility with the Bohler FOX CN 22/9 N filler material, conclusion supported by the lack of cracks or other imperfections in the welded joint areas (Figures 16c and 16d). The investigation of hardness showed an increase from $546 \mathrm{HV}_{0.2}$ in the $\mathrm{Al}_{\mathrm{x}} \mathrm{CrFeMnNi}$ base material up to $576 \mathrm{HV}_{0.2}$ in $\mathrm{HAZ}$. In the case of the AlCrFeMnNix HEA, the hardness value increased from $350 \mathrm{HV}_{0.2}$ in base material to $453 \mathrm{HV}_{0.2}$ in HAZ. Given the identical filler metal used for welding, the maximum hardness in both weld areas was $282 \mathrm{HV}_{0.2}$.

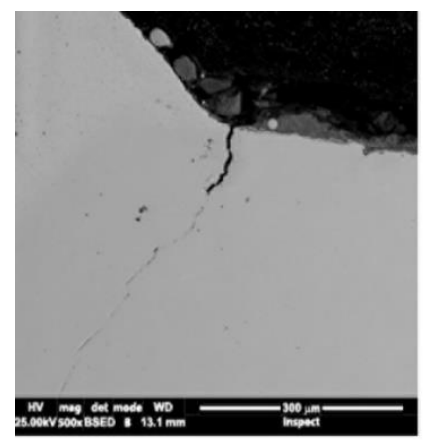

a)

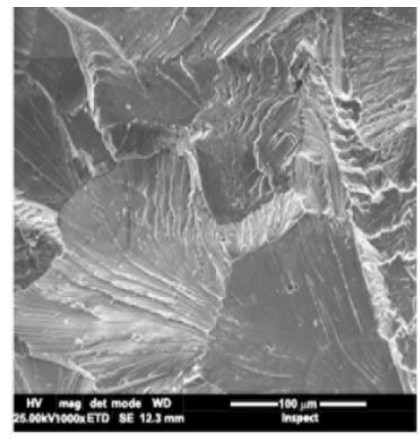

b)

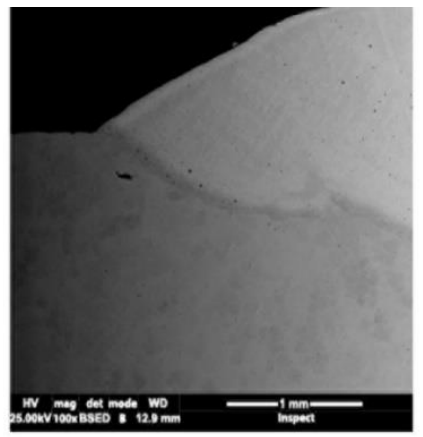

c)

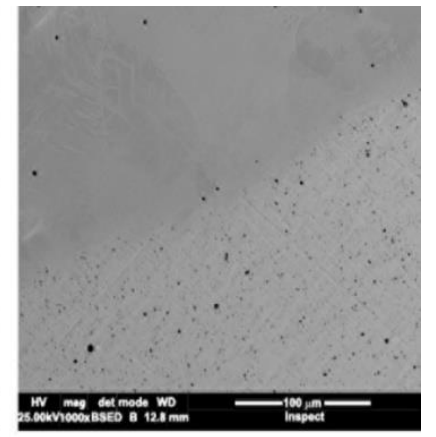

d)

Figure 16. Cross section of $\mathrm{Al}_{\mathrm{x}} \mathrm{CrFeMnNi}$ and $\mathrm{AlCrFeMnNix}$ welded samples: a) crack initiated on fusion line between weld and $\mathrm{Al}_{\mathrm{x}} \mathrm{CrFeMnNi}$ base material; b) brittle fracture surface of $\mathrm{Al}_{\mathrm{x}} \mathrm{CrFeMnNi} \mathrm{HEA}$; c) macrostructure of deposition by welding on $\mathrm{AlCrFeMnNix}$ alloy; d) $\mathrm{HAZ}$ of $\mathrm{AlCrFeMnNix}$ alloy

\section{Conclusions}

Based on the study related to welding of High-Entropy Alloys, several important conclusions can be highlighted, as follows:

- Due to the ability to maintain their properties at extreme temperatures, the High Entropy Alloys have a much larger applicability in the industry than the traditional (ordinary) alloys;

- Employing fusion welding sources with concentrated energy, as well as thermo-mechanical welding processes, high quality joints of $\mathrm{CoCrFeMnNi}$, AlCoCrCuFeNi, AlCrFeCoNi CoCrFeNi alloys, without filler material, can be achieved. Because of high brittleness of the AlxCrFeMnNi alloy, cracks may occur in the HAZ of the joint performed by SMAW. Applying similar welding conditions, the AlCrFeMnNix alloy shows good weldability which is demonstrated by the lack of defects in the joint areas.

- Using the FSW technique, the hardness in the Stir Zone increases due to the development of fine grains in this area. Employing the TIG and SMAW welding processes, a decrease of hardness in the fusion zone was noticed. When LBW and EBW were applied to join the HEAs plates, the hardness profile is strongly influenced by the chemical composition of the alloys. 
- Generally, a degradation of the HEAs mechanical properties was noticed, but this is an expected effect caused by welding. However, an appropriate selection of joining technique, as well as an optimal combination of process parameters led to performing quality joints.

Future research will focus on studying the improvement of mechanical characteristics of the welded joints by applying pre-heating or post-welding treatments.

Acknowledgements: This work was supported by the Romanian National Authority for Scientific Research, CNDI-UEFISCDI, through the project number PN-III-P1-1.2-PCCDI-2017-0875 (HEAPROTECT).

\section{References}

1.YE, Y.F., WANG, Q., LU, J., LIU, C.T., YANG, Y., Materials Today, 19(6), 2016, p. 349-362.

2. MIRACLE, D.B., SENKOV, O.N., Acta Materialia, 122, 2017, p. 448-511.

3. MURTY, B.S., YEH, J.W., RANGANATHAN, S., High-Entropy Alloys, Elsevier Inc., 2014.

4. LU, Z.P., WANG, H., CHEN, M.W., BAKER, I., YEH, J.W., LIU, C.T., NIEH, T.G., Intermetallics, 66, 2015, p. 67-76.

5. ZHAO, Y.J., QIAO, J.W., MA, S.G., GAO, M.C., YANG, H.J., CHEN, M.W., ZHANG, Y., Materials and Design, 96, 2016, p. 10-15.

6. VOICULESCU, I., GEANTA, V., VASILE, I.M., STEFANOIU, R., TONOIU, M., Journal of Optoelectronics and Advanced Materials, 15(7-8), 2013, p. 650 - 654.

7. VOICULESCU, I., GEANTA, V., STEFANOIU, R., PATROI, D., BINCHICIU, H., Rev. Chim., 64(12), 2013, p.1441

8. SANTODONATO, L.J., ZHANG, Y., FEYGENSON, M., PARISH, C.M., GAO, M.C., WEBER, R.J.K., NEUEFEIND, J.C., TANG, Z., LIAW, P.K., Nature Communications, 6, 2015, Art. 5964.

9. XI, J., YANG, Z., LU, Z., XINGYU, D.U., BANGSHENG, L., Materials Letters, 216, 2018, p. 144-146.

10. PICKERING, E.J., JONES, N.G., International Materials Reviews, 61(3), 2016, p. 183-202.

11. GALI, A., GEORGE, E.P., Intermetallics, 39, 2013, p. 74-78.

12. SENKOV, O.N., WILKS, G.B., MIRACLE, D.B., CHUANG, C.P., LIAW, P.K., Refractory high-entropy alloys, Intermetallics, 18(9), 2010, p. 1758-1765.

13. SENKOV, O.N., WILKS, G.B., SCOTT, J.M., MIRACLE, D.B., Intermetallics, 19(5), 2011, p. 698-706.

14. WU, Z., BEI, H., PHARR, G.M., GEORGE, E.P., Acta Materialia, 81, 2014, p. 428-441.

15. GLUDOVATZ, B., HOHENWARTER, A., CATOOR, D., CHANG, E.H., GEORGE, E.P., RITCHIE, R.O., Science, 345(6201), 2014, p. 1153-1158.

16. HE, J.Y., WANG, H., HUANG, H.L., XU, X.D., CHEN, M.W., WU, Y., LIU, X. J., NIEH, T.G., AN, K., LU, Z.P., Acta Materialia, 102, 2016, p. 187-196.

17. LU, Y.P., GAO, X.Z., JIANG, L., CHEN, Z.N., WANG, T.M., JIE, J.C., KANG, H.J., ZHANG, Y.B., GUO, S., RUAN, H.H., ZHAO, Y.H., CAO, Z.Q., LI, T.J., Acta Materialia, 124, 2017, p. 143-150.

18. TANG Z., YUAN T., TSAI C. W., YEH J. W., LUNDIN C. D., LIAW P. K., Acta Materialia, 99, 2015, p. 247-258.

19. VOICULESCU, I., GEANTA, V., IONESCU, M., Annals of "Dunarea de Jos" University of Galati, Fascicle XII, Welding Equipment and Technology, 26, 2015, p. 5-11.

20. VOICULESCU, I., GEANTA, V., SCUTELNICU, E., STEFANOIU, R., ROTARIU, A., SOLOMON, G., Proceedings of the $1^{\text {st }}$ World Conference on Advanced Materials for Defense, AuxDefense 2018, Lisbon, 2018, p. 201-202.

21.YOUSSEF, K.M., ZADDACH, A.J., NIU, C., IRVING, D.L., KOCH, C.C., Materials Research Letters, 3, 2015, p. 95-99.

22. FU, Z., JIANG, L., WARDINI, J.L., MACDONALD, B.E., WEN, H., XIONG, W., ZHANG, D., ZHOU, Y., RUPERT, T.J., CHEN, W., LAVERNIA, E.J., Science Advances, 4(10), 2018, p. 1-8.

23. GUO, T., LI, J., WANG, J., WANG, W.Y., LIU, Y., LUO, X., KOU, H., BEAUGNON, E., Materials Science and Engineering, 729, 2018, p. 141-148.

24.WANG, B., FU, A., HUANG, X., LIU, B., LIU Y., LI, Z., ZAN, X., Journal of Materials Engineering and Performance, 25(7), 2016, p. 2985-2992. 
25.BHATTACHARJEE, P.P., SATHIARAJ, G.D., ZAID, M., GATTIJ, R., CHI, LEE, CHE-WEI, TSAI, JIENWEI, YEH, Journal of Alloys and Compounds, 587, 2017, p. 544-552.

26. TSAO, L.C., CHEN, C.S., CHU, C.P., Materials \& Design, 36, 2012, p. 854-858.

27. LI, Y., LEE, J., KANG, B., HONG, S.H., www.researchgate.net, 2017, p. 1-19.

28. SENKOV, O.N., SENKOVA, S.V., WOODWARD, C., MIRACLE, D.B., Acta Materialia, 61, 2013, p. $1545-1557$.

29.HAN, Z.D., CHEN, N., ZHAO, S.F., FAN, L.W., YANG, G.N., SHAO, Y., YAO, K.F., Intermetallics, 84, 2017, p. 153-157.

30. LI, Q., ZHANG, H., LI, D., CHEN, Z., HUANG, S., LU, Z., YAN, H., Materials, 12(3), 533, 2019, p. 1-14.

31.ZHANGA, B., GAOBC, M.C., ZHANGA, Y., GUO, S.M., Journal Data in Brief, 5, 2015, p. 730-735.

32. GUO, N.N., WANG, L., LUO, L.S., LI, X.Z., SU, Y.Q., GUO, J.J., FU, H.Z., Materials \& Design, 81, 2015, p. $87-94$

33. SENKOV, O.N., WOODWARD, C.F., Materials Science and Engineering, 529, 2011, p. 311-320.

34. ZHANG, Y., ZUO, T. T., TANG, Z., GAO, M.C., DAHMEN, K.A., LIAW, P.K., LU, Z.P., Progress in Materials Science, 61, 2014, p. 1-93.

35. GAO, M.C., YEH, J. W., LIAW, P.K., ZHANG, Y., Springer International Publishing Switzerland, 2016, p. $1-15$.

36. OTTO, F., DLOUHY, A., SOMSEN, C.H., BEI, H., EGGELER, G., GEORGE, E.P., Acta Materialia, 61, 2013, p. 5743-5755.

37. ZHEREBTSOV, S., STEPANOV, N., IVANISENKO, Y., SHAYSULTANOV, D., YURCHENKO, N., KLIMOVA, M., SALISHCHEV, G., Metals, 8(2), 123, 2018, p. 1-13.

38. TSAI, S.P., TSAIY, T., YU-WENCHEN, Y.W., CHEN, P.J., CHIU, P.H., CHEN, C.Y., LEE, W., YEH, J.W., YANG, J.R., Materials Characterization, 147, 2019, p. 193-198.

39. WU, Z., DAVID, S.A., LEONARD, D.N., FENG, Z., BEI, H., Science and Technology of Welding \& Joining, 2018, 23, p. 585-595.

40. WU, Z., DAVID, S.A., FENG, Z., BEI, H., Scripta Materiala, 2016, 124, p. 81-85.

41. KASHAEV, N., VENTZKE, V., STEPANOV, N., SHAYSULTANOV, D., SANIN, V., ZHEREBTSOV, S., Intermetallics 2018, 96, p. 63-71.

42. ZHEREBTSOV, S., STEPANOV, N., SHAYSULTANOV, D., MALOPHEYEV, S., VYSOTSKIY, I., SANIN, V., KASHAEV, N., KAIBYSHEV, R., Materials Science Forum, 2018, 941, p. 919-924.

43. NAM, H., PARKA, C., MOON, J., NA, Y., KIM, H., KANG, N., Materials Science \& Engineering: A, 742, 2019, p. 224-230.

44. NAM, H., PARK, C., KIM, C., KIM, H., KANG, N., Science and Technology of Welding and Joining, 23(5), 2018, p. 420-427.

45. LIU, W.H., WU, Y., HE, J.Y., NIEH, T.G., LU, Z.P., Scripta Materialia, 68, 2013, p. 526-529.

46. JO, M.G., KIM, H.J., KANG, M., MADAKASHIRA, P.P., PARK, E.S., SUH, J.Y., KIM, D.I., HONG, S.T., HA, N.H., Metals and Materials International, 24(1), 2018, p. 73-83.

47. SCHUH, B., MENDEZ, F., VÖLKER, B., GEORGE, E.P., CLEMENS, H., HOHENWARTER, A., Acta Materialia, 96, 2015, p. 258-268.

48. SHAYSULTANOV, D., STEPANOV, N., MALOPHEYEV, S., VYSOTSKIY, I., SANIN, V., MIRONOV, S., KAIBYSHEV, R., SALISHCHEV, G., ZHEREBTSOV, S., Materials Characterization, 145, 2018, p. 353361.

49. WEN, L.H., KOU, H.C., LI, J.S., CHANG, H., XUE, X.Y., ZHOU, L., Intermetallics, 17(4), 2009, p. 266269.

50. KUZNETSOV, A.V., SHAYSUlTANOV, D.G., STEPANOV, N.D., SALISHCHEV, G.A., SENKOV, O.N., Materials Science and Engineering: A, 533, 2012, p. 107-118.

51. MARTIN, A.C., FINK, C., Welding in the World, 63, 2019, p. 739-750.

52. BERGMANN, J.P., BIELENIN, M., HERZOG, R.A., HILDEBRAND, J., RIEDEL, I., SCHRICKER, K., TRUNK, C., WORTHMANN, K., Proceedings in Applied Mathematics and Mechanics, 17, 2018, p. 405-406.

53. MUNITZ, A., SALHOV, S., HAYUN, S., FRAGE, N., Journal of Alloys and Compounds, 683, 2016, pp. 221-230.

54. QIAO, J.W., MA, S.G., HUANG, E.W., CHUANG, C.P., LIAW, P.K., ZHANG, Y., Materials Science Forum, 688, 2011, p. 419-425. 
55.LYU, Z., FAN, X., LEE, C., WANG, S.Y., FENG, R., LIAW, P.K., Journal of Materials Research, 33, 2018, p. 2988-3010.

56.WANG, W.R., WANG, W.L., YEH, J.W., Journal of Alloys and Compounds, 589, 2014, p. 143-152.

57. SOKKALINGAM, R., MISHRA, S., CHEETHIRALA, S.R., MUTHUPANDI, V., SIVAPRASAD, K., Metallurgical and Materials Transactions, 48, 2017, p. 3630-3634.

58. SOKKALINGAM, R., SIVAPRASAD, K., MUTHUPANDI, V., DURAISELVAM, M., Key Engineering Materials, 775, 2018, p. 448-453.

59. GUO, J., TANG, C., ROTHWELL, G., LI, L., WANG, Y.C., YANG, Q., REN, X., Entropy, 214(4), 2019, p. 1-17.

60. NAHMANY, M., HOOPER, Z., STERN, A., GEANTA, V., VOICULESCU, I., Metallography Microstructure and Analysis, 5, 2016, p. 229-240.

61. ZHU, Z.G., SUN, Y.F., GOH, M.H., NG, F.L., NGUYEN, Q.B., FUJII, H., NAI, S.M.L., WEI, J., SHEK, C.H., Materials Letters, 205, 2017, p. 142-144.

62. LIU, J., GUO, X., LIN, Q., HE, Z., AN, X., LI, L., LIAW, P.K., LIAO, X., YU, L., LIN, J., XIE, L., REN, J., ZHANG, Y., SCIENCE CHINA Materials, 62(6), 2018, p. 853-863.

63. ZHU, Z.G., SUN, Y.F., NG, F.L., GOH, M.H., LIAW, P.K., FUJII, H., NGUYEN, Q.B., XU, Y., SHEK, C.H., NAI, S.M.L., WEI, J., Materials Science \& Engineering: A, 711, 2018, p. 524-532.

Manuscript received: 28.10 .2019 